JURNAL PENDIDIKAN, p-ISSN 2715-095X, e-ISSN 2686-5041

Volume 30, No.2, Juli 2021 (199-206)

Online: http://journal.univetbantara.ac.id/index.php/jp

\title{
Pembelajaran Daring Dengan Menggunakan Metode Information Search Mata Pelajaran Bahasa Indonesia Teks Iklan Di SMP Negeri 3 Kasihan Bantul Pada Kondisi Covid-19
}

\author{
Evi Rofikoh ${ }^{1}$ dan Wulan Dari ${ }^{2}$ \\ Pendidikan Bahasa dan Sastra Indonesia, Fakultas Keguruan dan Ilmu Pendidikan, Universitas Ahmad \\ Dahlan, Jalan Ring Road Selatan, Kragilan, Tamanan, Kec. Banguntapan, Bantul, Daerah Istimewa \\ Yogyakarta 55191, E-mail: evirofikoeh@gmail.com
}

Received: May 2, $2021 \quad$ Accepted: May 16, $2021 \quad$ Online Published: Juni 26, 2021

\begin{abstract}
Abstrak: Pembelajaran daring adalah pembelajaran yang menggunakan media internet tanpa ada batasan ruang dan waktu dalam menjalankan proses pembelajaran. Pembelajaran daring adalah solusi untuk mengatasi problematika pendidikan akibat pandemi Covid-19 yang terjadi saat ini. Penelitian ini mencoba menjelaskan Pembelajaran Daring Dengan Menggunakan Metode Information Search Mata Pelajaran Teks Iklan di SMP Negeri 3 Kasihan Bantul Pada Kondisi Covid-19 dan Bagaimana Evaluasi dengan menggunakan Metode Information Search Pelajaran Teks Iklan di SMP Negeri 3 Kasihan Bantul pada kondisi Covid-19. Tujuan dari penelitian ini adalah untuk memberikan informasi mengenai Pembelajaran Daring Dengan Menggunakan Metode Information Search Mata Pelajaran Pelajaran Teks Iklan di SMP Negeri 3 Kasihan Bantul Pada Kondisi Covid-19 dan Bagaimana Evaluasi Pembelajaran Daring dengan menggunakan Metode Information Search Mata Pelajaran Teks Iklan di SMP Negeri 3 Kasihan Bantul pada kondisi Covid-19. Penelitian ini diklasifikasikan sebagai penelitian kualitatif deskriptif.
\end{abstract}

Kata-kata Kunci: Metode pembelajaran, Teks Iklan, Information Search, SMP

\section{Online Learning Using the Information Search Method for Indonesian Language Subjects Advertisement Text at SMP Negeri 3 Kasihan Bantul In the Condition of Covid-19}

\author{
Evi Rofikoh' ${ }^{1}$ and Wulan Dari ${ }^{2}$
}

\begin{abstract}
Pendidikan Bahasa dan Sastra Indonesia, Fakultas Keguruan dan Ilmu Pendidikan, Universitas Ahmad Dahlan, Jalan Ring Road Selatan, Kragilan, Tamanan, Kec. Banguntapan, Bantul, Daerah Istimewa Yogyakarta 55191, E-mail: evirofikoeh@gmail.com
\end{abstract}

\begin{abstract}
Online learning is learning that uses internet media without any limitations of space and time in carrying out the learning process. Online learning is a solution to overcome educational problems due to the current Covid-19 pandemic. This study tries to explain Online Learning Using the Information Search Method for Advertising Text Subjects at SMP Negeri 3 Kasihan Bantul in the Covid-19 Condition and how to evaluate using the Information Search Method for Advertising Text Lessons at SMP Negeri 3 Kasihan Bantul in the Covid-19 condition. The purpose of this study is to provide information about Online Learning Using the Information Search Method for Advertising Text Subjects at SMP Negeri 3 Kasihan Bantul in the Covid-19 Condition and How to Evaluate Online Learning using the Information Search Method for Advertising Text Subjects at SMP Negeri 3 I feel sorry for Bantul in the Covid-19 condition. This research is classified as a descriptive qualitative research.
\end{abstract}

Keywords: Learning method, Advertising Text, Information Search, SMP 


\section{Pendahuluan}

Pendidikan merupakan suatu pengajaran yang diajarkan oleh guru kepada siswa dengan tujuan untuk mengembangkan kemampuan yang ada pada diri siswa supaya memiliki kepribadian spriritual, dan kecerdasan yang baik, lewat proses belajar yang baik dan teratur. Peran pendidikan untuk menjamin keberlangsungan hidup suatu bangsa, karena lewat pendidikan yang baik maka akan menciptakan peserta didik yang cerdas dan berakhlak baik, yang siap dengan perubahan zaman yang dipenuhi dengan tantangan. Pada kenyataanya problematika pembelajaran di Indonesia saat ini muncul dari akibat wabah penyakit pandemi corona (Covid-19), bermula dari akhir bulan Januari 2020 penyakittersebut muncul dari Wuhan, Cina. Pada sektor pendidikan terdampak akibat penyebaran virus corona yang terjadi sangat cepat dan skala luas ke berbagai negara di dunia. Akibat virus corona banyak kegiatan yang harus terhenti dan dialihkan dengan cara WFH (Work From Home), begitu juga dengan kegiatan dibidang pendidikan. Seluruh kegiatan di sektor pendidikan diliburkan, hal ini dampak dari kebijakan pemerintah. Kebijakan ini terapkan untuk memutuskan mata rantai penyebaran virus corona. Dengan itu seluruh kegiatan khususnya pada sektor pendidikan tidak melakukan kegiatan seperti biasa agar dapat di minimalisir penyebaran virus Covid-19 (Purwanto, 2020).

Banyak dilapangan guru masih sering mengabaikan perkembangan generasi siswanya sehingga guru masih mengajar dengan cara yang tradisional (ceramah) dan mengakibatkan peserta didik kurang puas dengan penggunaan metode belajar yang diajarkan oleh guru sehingga tujuan pembelajaran yang sudah tertulis tidak tercapai dengan maksimal dan peserta didik mengalami kesulitan ketika belajar (Daud, 2020). Biasanya kegiatan belajar didalam kelas masih di dominasi oleh guru dan pesertadidik hanya disibukkan dengan mendengarkan ceramah dan mengerjakan tugas yang hanya memanfaatkan buku paket saja, tidak diberi peluang untuk mencari jawaban dari sumber lain selain buku paket. Hal itu yang menjadikan siswa tidak merdeka dalam belajar.

Kondisi tersebut menyebabkan pembelajaran berbasis teknologi informasi jarang dilakukan oleh guru-guru di sekolah, padahal pembelajaran seperti ini sangat dituntut untuk pendidikan di era abad 21. Dengan pembelajaran berbasis teknologi informasi maka siswa mampu berpikir secara kritis, kreatif, inovatif, kolaboratif, dan komunikatif. Akan tetapi fakta di atas menjadikan para siswa di sekolah-sekolah Indonesia tidak memiliki kemampuan berpikir tingkat tinggi yang baik. Pembelajaran di kelas didominasi oleh pembelajaran yang konvensional, siswa hanya dijadikan objek pembelajaran, tidak diberikan kesempatan untuk memanfaatkan perkembangan teknologi informasi yang dapat mengasah ketrampilan berpikir mereka. Hasilnya, para alumni lembaga pendidikan di Indonesia mengalami kesulitan untuk bersaing dengan tantangan abad 21 karena $70 \%$ siswa tidak memiliki kemampuan berpikir tingkat tinggi (Pranoto, 2019).

Berdasarkan latar belakang tersebut, peneliti tertarik untuk mengungkap lebih mendalam tentang proses pembelajaran daring dengan menggunakan metode information search mata pelajaran teks Iklan di SMP Negeri 3 Kasihan Bantul pada kondisi covid-19. Secara spesifik, penelitian ini bertujuan untuk menjawab pertanyaan sebagai berikut: bagaimana strategi pembelajaran berbasis teknologi informasi untuk pembelajaran secara daring di Negeri 3 Kasihan Bantul pada kondisi covid-19. Hasil penelitian ini diharapkan dapat memberikan wawasan ilmiah kepada pemangku jabatan, praktisi pendidikan dan khususnya para guru di sekolah menengah dalam melaksanakan pembelajaran berbasis 
teknologi di kelas. Penggunaan media online atau media dan metode pembelajaran berbasis multimedia merupakan salah satu solusi untuk membuat peserta didik mampu memahami materi pelajaran dengan baik. Hal ini sejalan dengan hasil penelitian Ibrahim \& Suardiman (2014) yang menunjukkan bahwa ada pengaruh positif penggunaan e-learning terhadap motivasi dan prestasi belajar peserta didik di SMP Negeri 3 Kasihan Bantul. Pembelajaran daring menggunakan media online telah diterapkan di SMP Negeri 3 Kasihan Bantul sejak mulai diberlakukannya work from home pada 16 Maret 2020 selama masa pandemi covid19. Media online yang digunakan seperti youtube, whatsapp group, google classroom, dan quizzes. Materi diberikan dalam bentuk powerpoint, video singkat, dan bahan bacaan. Peneliti menggunakan Kompetensi Dasar 3.3 Mengidentifikasi informasi teks iklan, slogan, atau poster (yang membuat bangga dan memotivasi) dari berbagai sumber yang dibaca dan didengar dan 4.3 Menyimpulkan isi iklan, slogan, atau poster (membanggakan dan memotivasi) dari berbagai Sumber. Melalui Pembelajaran Daring Dengan Menggunakan Metode Information Search Mata Pelajaran Teks Iklan, diharapkan dapat meningkatkan semangat belajar peserta didik, sehingga tujuan pembelajaran yang ditargetkan dapat tercapai.

\section{Metode Penelitian}

Penelitian ini menggunakan pendekatan kualitatif dengan metode deskriptif. Tujuan penelitian adalah untuk mengetahui penerapan metode Information Search untuk Pembelajaran Daring Mata Pelajaran Bahasa Indonesia materi Teks Iklan, Slogan, dan Poster di SMP Negeri 3 Kasihan Bantul Pada Kondisi Covid-19 dan diharapkan dapat meningkatkan semangat belajar peserta didik, sehingga tujuan pembelajaran yang ditargetkan dapat tercapai. Sumber data primer adalah wawancara yang dilakukan melalui Google Form. Sumber data pendukung adalah teori tokoh, dan penelitian yang relevan yang ditulis oleh penulis lain. Data yang diperoleh di analisis secara deskriptif-kualitatif. Teknik yang digunakan dalam penelitian ini adalah deskriptif kualitatif untuk mengolah data dalam bentuk skor dari penilaian oleh validator dan respon siswa, sedangkan deskriptif kualitatif untuk mendeskripsikan data berupa komentar saran perbaikan dari validator.

Data penelitian ini diambil dari jawaban hasil kuesioner yang dilakukan kepada siswa mata pelajaran bahasa Indonesia. Kuesioner digunakan sebagai data yang berisi penerapan metode Information Search untuk Pembelajaran Daring Mata Pelajaran Bahasa Indonesia materi Teks Iklan, Slogan, dan Poster pada siswa kelas VIII. Subjek utama dalam penelitian ini adalah siswa mata pelajaran bahasa Indonesia Kelas VIII A SMP Negeri 3 Kasihan Bantul yang terdiri dari 32 siswa sumber data utama. Subjek utama pada penelitian ini yaitu mulai hasil data dari pengisian kuesioner berjudul "Penerapan metode Information Search untuk Pembelajaran Daring Mata Pelajaran Bahasa Indonesia", serta upaya peranan metode pembelajaran.

\section{Hasil Penelitian}

Menurut data yang diperoleh peneliti diatas menunjukan bahwa seluruh siswa kelas VIII A di SMP Negeri 3 Kasihan Bantul untuk menunjang keberlangsungan pembelajaran daring dengan menggunakan metode Information Search mata pelajaran Bahasa Indonesia siswa biasa menggunakan handphone atau laptop untuk akses internet saat pembelajaran daring. Menurut data yang diperoleh peneliti diatas menunjukan bahwa seluruh siswa Kelas VIII A di SMP Negeri 3 Kasihan Bantul dengan adanya teknologi informasi mempermudah 
kegiatan pembelajaran ketika harus dilakukan secara daring seperti saat kondisi pandemi. Menurut data yang diperoleh peneliti diatas menunjukan bahwa seluruh siswa Kelas VIII A di SMP Negeri 3 Kasihan Bantul berpendapat bahwa kekurangan pembelajaran daring menggunakan metode Information Search ini yaitu, selain siswa tidak bisa berinteraksi secara langsung dengan guru, terdapat faktor lain yang menjadi pembelajaran tidak berlangsung secara maksimal karena diharuskan menggunakan paket data.

\section{Pembahasan}

\section{Pembelajaran daring di SMP Negeri 3 Kasihan Bantul}

Pembelajaran daring menurut Gunawan yaitu pembelajaran dimana siswa menyelesaikan tugasnya dan mengambil keputusan setiap waktu dengan memanfaatkan teknologi (Gunawan, 2020). Menurut Nakayama (Nakayama, 2007) pembelajaran daring yaitu proses pembelajaran yang memanfaatkan jaringan internet. Suryawan (Suryawan, 2020) berpendapat pembelajaran daring yaitu kegiatan yang bisa dilakukan dari rumah dan bisa dilakukan kapan saja sehingga tidak menjadikan masalah karena pembelajrannya tidak terikat oleh waktu. Pembelajaran daring menurut Mulyasa (Mulyasa, 2013) yaitu pembelajaran yang pelaksanaannya dilakukaan secara virtual dengan aplikasi virtual yang tersedia. Berdasarkan uraian dari pengertian diatas maka dapat disimpulkan bahwa pembelajaran daring semua bisa berjalan dengan baik seperti biasa dengan dukungan internet dan pembelajarannya tidak terikat oleh ruang dan waktu. Pembelajaran daring merupakan inovasi pendidikan dan jawaban dari kurangnya ketersediaan sumber belajar yang variatif. Dalam pembelajaran daring siswa memiliki waktu yang luas untuk belajar setaip waktu. Guru dan peserta didik bisa berinteraksi dengan menggunakan aplikasi seperti classroom, zoom, whatsap group, dan lain sebagainya. Akan tetapi, pembelajaran daring harus memperhatikan kompetensi yang diajarkan jadi guru harus menyadari bahwa pembelajaran memiliki sifat yang kompleks karena didalamnya terdapat aspek pedagogis, psikologis, dan diktatis. Maka dari itu pembelajaran daring tidak hanya memindahkan materi, soal- soal, dan tugas melalui internet tetapi juga harus harus direncanakan, dilaksanakan, serta dievaluasi sama halnya dengan pembelajaran yang terjadi di kelas.

Penelitian relevan yang sesuai dengan judul yaitu dalam pembelajaran dengan menggunakan metode sistem daring menjadi bahasan yang menarik dalam masa pandemi Wabah Covid-19 ini. Berdasarkan kondisi peserta didik, kondisi terhadap pembelajaran sistem digital dapat dilakukan. Namun ini dapat memberikan pengaruh terhadap kondisi psikis peserta didik sehingga perlu ada solusi lain seperti halnya melakukan beberapa aktivitas yang dapat meredakan dan menyelesaikan masalah yang ditimbulkan oleh hambatan yang muncul. Sistem pembelajaran daring ini dapat dijadikan sebagai modal awal bagi peserta didik dalam melaksanakan pembelajarannya dikemudian hari (Dindin Jamaluddin, 2020). Pembelajaran di SMP Negeri 3 Kasihan Bantul sudah menggunakan sistem daring, adapun aplikasi yang dipakai oleh beberapa guru yaitu metode diskusi dengan menggunakan WA group, Google Classroom, metode ceramah dengan menggunakan video aplikasi zoom, metode resitasi dengan siswa diberikan materi kemudian disuruh untuk membuat resume, metode problem based learning dengan cara siswa diberikan sebuah kasus untuk kemudian dipecahkan masalahnya bersama teman kelompoknya ataupun juga bisa di pecahkan secara individu, metode discovery learning dengan cara siswa mengembangkan dirinya menjadi lebih aktif dan mandiri dalam mencari jawabannya, dan masih banyak lainnya. Akan tetapi dari sekaian banyak aplikasi daring 
tersebut untuk mata pelajaran Bahasa Indonesia hanya menggunakan aplikasi group WA dan Google Classroom. Dikarenakan penggunaannya yang mudah dan praktis jika diterapkan untuk pembelajaran daring pada mata pelajaran Bahasa Indonesia. Selanjutnya untuk mengirim jawaban dari pertanyaan yang dikirim oleh guru sebelumnya dilakukan dengan cara siswa mengirim jawaban kepada guru melalui group WA dengan cara memfoto jawaban yang sudah ditulis sebelumnya, melalui Google Classroom dengan cara mengunggahnya, atau siswa juga diberi kesempatan setiap hari Jumat untuk mengumpulkan tugas ke Sekolah.

\section{Metode information search pada mata pelajaran bahasa Indonesia}

Menurut Sodikin, M. A., Sumardi, K., dan Berman, E. T. metode Information Search adalah metode pembelajaran yang memberikan kebebasan kepada siswa mencari jawaban dari pertanyaan yang diberikan oleh guru melalui berbagai sumber yang ada, sehingga menumbuhkan ketertarikan siswa pada materi yang dibahas (Sodikin, 2018). Menurut Hisyam Zaini (Zaini, 2008) metode Information Search yaitu metode yang sama dengan ujian open book, dimana peserta didik mencari jawaban untuk menjawab soal-soal yang diberikan oleh guru. Hamruni (Hamruni, 2011) berpendapat bahwa metode Information Search yaitu metode yang memberikan suasana baru pada siswa untuk belajar lewat perpustakaan, warnet, mencari jurnal, dan sumber belajar yang lain. Berdasarkan uraian dari pengertian diatas maka dapat disimpulakan bahwa metode Information Search adalah metode pembelajaran yang memberikan kebebasan kepada siswa menacari jawaban dari soal yang diberikan oleh guru melalui berbagai sumber yang ada, metode tersebut juga dapat meningkatkan efektifitas pembelajaran Pendidikan Agama Islam, dan siswa mampu memahami materi dengan mudah. Penelitian relevan yang sesuai dengan judul yaitu berdasarkan hasil pembahasan dan analisis yang sudah dilakukan oleh Sapuadi dan Yana Sari (Sari, 2019), penelitian dapat disimpulkan bahwa: Keterlaksanaan penerapan metode pembelajaran Information Search mengalami perbaikan secara gradual pada setiap siklusnya yaitu dari kondisi kurang baik menjadi kondisi baik dan pembelajaran dengan menggunakan metode Information Search memiliki dampak yang signifikan dalam peningkatkan prestasi belajar peserta didik yang ditandai dengan peningkatan ketuntasan belajar peserta didik dalam setiap siklus, yaitu siklus I (64\%), siklus II (74\%), siklus III (94\%). Pada penelitian yang dilakukan oleh Nur Laela Dewi, Ahmad Izza Muttaqin, Al Muftiyah (Nur Laela Dewi, 2019) penerapan metode Information Search yang merupakan strategi pembelajaran kurikulum 2013. Adanya perkembangan zaman terdapat pula kemajuan ilmu pengetahuan dan teknologi, pada dunia pendidikan maupun dalam bidang yang lain guru harus mampu menguasai metode pembelajaran HOTS (Higher Order of Thingking Skill) dalam tuntuntan kurikulum 2013 sekarang ini. Penerapan metode Information Search yang dilakukan pada siswa kelas X MIPA 1 siswa lebih aktif dalam belajar dan lebih berfikir kritis dalam memahaminya karena siswa lebih leluasa dalam mencari jawaban sesuai dengan topik pembelajaran yang dibahas. Pada penelitian lain yang dilakukan oleh Atiah Dwi Rusanti penerapan metode Information Search hasil penelitian menunjukan bahwa penerapanmetode Information Search mampu meningkatkan minatsiswa dilihat dari perubahan sikap siswadalam proses pembelajaran semakin aktif dan antusias meningkat dan penerapan metode Information Search dalam pembelajaran Fiqih Ibadah dapat berhasilkan dilihat dari pencapaian pembelajaran siswa kelas X SMK Muhammadiyah 1 Surakarta mencapai KKM. Pada aspek penilaian, keberhasilan pembelajaran tercapai dilihat darihasil rata-rata nilai UTS semester genapkelas XA yaitu 
81,4 XC yaitu 79,9 dan X E 79,9. Pada aspek praktek dan kelakuan siswa beribadah dapat dikatakan linier dengan apa yang diajarkan di kelas sesuai dengan praktek dilapangan saat melaksanakan shalat berjamaah di masjid sekolah. Yang terjadi pada fakta lapangan siswa sekolah jenjang menengah pertama pada zaman sekarang sudah mulai menjadikan smartphone adalah kebutuhan primer mereka, selain untuk menjadi komunikasi dengan keluarga dan teman. Mereka menggunakan smartphone sebagai alat untuk menggali informasi dengan adanya internet ataupun aplikasi lainnya yang bisa menunjang mereka untuk belajar mandiri dan aktif. Ponsel tidak hanya digunakan untuk komunikasi saja akan tetapi dalam dunia pendidikan ponsel juga bisa dipakai sebagai media dan sumber belajar.

\section{Perangkat Pembelajaran...}

- Memiliki perangkat pembelajaran daring

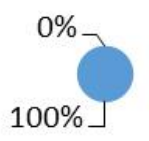

Gambar 1. Persentase Memiliki Perangkat Daring

Menurut data yang diperoleh peneliti diatas menunjukan bahwa seluruh siswa kelas VIII A di SMP Negeri 3 Kasihan Bantul untuk menunjang keberlangsungan pembelajaran daring dengan menggunakan metode Information Search mata pelajaran Bahasa Indonesia siswa biasa menggunakan handphone atau laptop untuk akses internet saat pembelajaran daring. Hal ini dikarenakan zaman sekarang sudah mulai menjadikan smartphone adalah kebutuhan primer mereka.

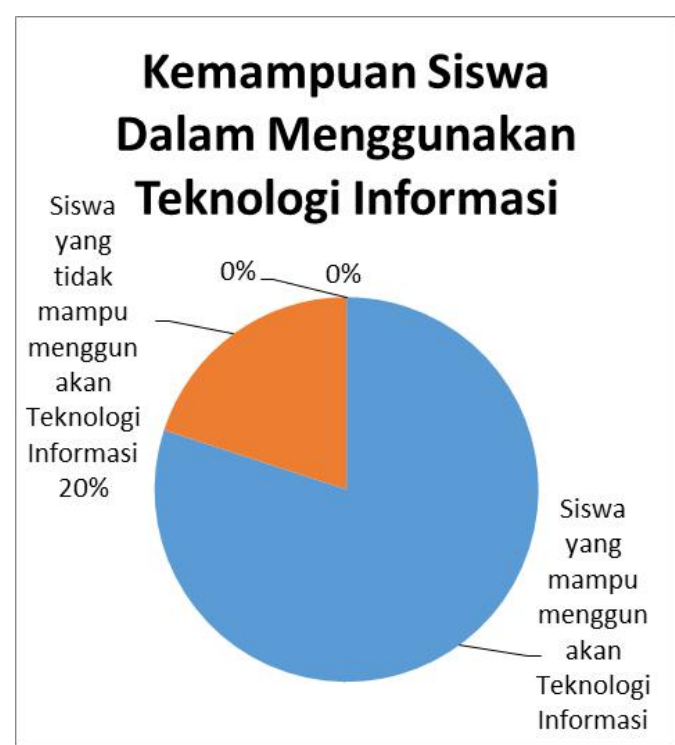

Gambar 2. Persentase Kemampuan Siswa dalam Menggunakan Teknologi

Menurut data yang diperoleh peneliti diatas menunjukan bahwa seluruh siswa Kelas VIII A di SMP Negeri 3 Kasihan Bantul dengan adanya teknologi informasi mempermudah kegiatan pembelajaran ketika harus dilakukan secara daring seperti saat sekarang, hal ini 
dikarenakan dengan memanfaatkan internet menjadikan belajar lebih fleksibel karena siswa dengan sendirinya bisa mengakses informasi dengan mudah dan cepat dalam menyelesaikan tugas yang diberikan oleh guru.

Gambar 3. Kelemahan Pembelajaran Daring

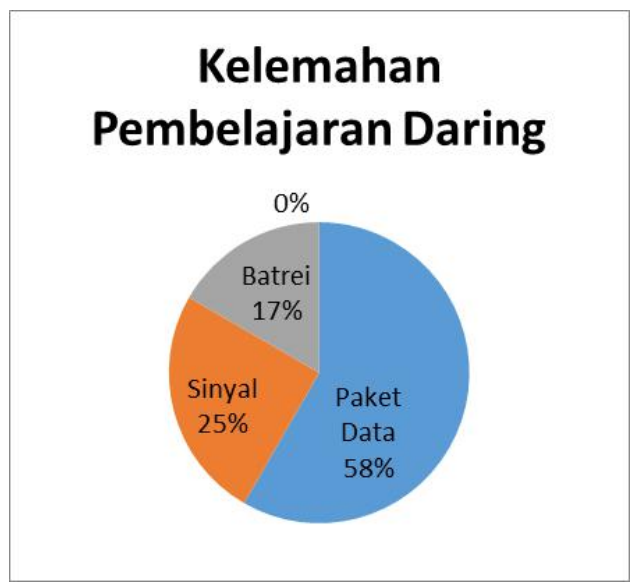

Menurut data yang diperoleh peneliti diatas menunjukan bahwa seluruh siswa Kelas VIII A di SMP Negeri 3 Kasihan Bantul berpendapat bahwa kekurangan pembelajaran daring menggunakan metode Information Search ini yaitu, selain siswa tidak bisa berinteraksi secara langsung dengan guru, terdapat faktor lain yang menjadi pembelajaran tidak berlangsung secara maksimal karena diharuskan menggunakan paket data ketika pembelajaran daring berlangsung, serta harus ditunjang kekuatan sinyal yang bagus. Jadi hal itu menjadi poin penting untuk keberlangusngan pembelajaran daring.

Dari teori-teori yang sudah dipaparkan oleh tokoh-tokoh di atas mengenai pembelajaran daring dan metode Information Search, ditambah dengan wawancara melalui kuesioner dalam google form yang dilakukan oleh peneliti dengan guru mata pelajaran Bahasa Indonesia dan siswa di SMP Negeri 3 Kasihan Bantul maka peneliti menyimpulkan bahwa penggunaan metode Information Search saat pembelajaran daring di mata pelajaran Bahasa Indonesia bisa diterapkan karena ditengah-tengah problematika pembelajaran saat ini dengan keadaan Indonesia yang terdampak Covid-19 memang sedang menjadi hal utama untuk segara di pecahkan untuk mencari solusinya. Sesuai dengan teori maka penggunaan metode Information Search bisa gunakan untuk mata pelajaran Bahasa Indonesia. Karena materi Bahasa Indonesia yang pembahasannya sangat luas sehingga tidak akan efektif jika dijelaskan hanya melalui metode ceramah, tetapi jika terdapat tampilan video atau gambar yang bisa diambil atau dicari lewat internet akan menjadi penjelas dan alat bantu untuk siswa dalam memahami materi tidak hanya dengan bayangan pemikirannya saja

\section{Simpulan dan Saran}

Berdasarkan pembahasan di atas maka peneliti dapat menyimpulkan bahwa:

(a). Pembelajaran daring adalah pembelajaran yang menggunakan media internet tanpa ada batasan ruang dan waktu dalam menjalankan proses pembelajaran. (b). Metode Information Search adalah metode pembelajaran yang memberikan kebebasan kepada siswa mencari jawaban dari pertanyaan yang diberikan oleh guru melalui berbagais umber yang ada, sehingga menumbuhkan ketertarikan siswa padamateri yang dibahas. (c). Penggunaan Metode Information Search di SMP Negeri 3 Kasihan Bantul sesuai untuk digunakan pada mata pelajaran Bahasa Indonesia seperti Materi Teks Iklan, Slogan, dan 
Poster. Metode Information Search bisa digunakan untuk pembelajaran yang lebih efektif dan efisien. Untuk menciptakan anak didik yang lebih mandiri dan aktif dan menyelesaikan masalah. Ditambah dengan problematika pembelajaran yang saat ini terjadi yaitu wabah virus corona (Covid-19) pembelajaran harus tetap terlaksana dengan mandiri dirumah masing-masing. Semoga dengan hadirnya teknlogi dalam memfasilitasi pembelajaran daring (dalam jaringan) secara online oleh guru masing-masing siswa bisa menjadikan jalan keluar dari kasus ini.

\section{Daftar Rujukan}

Gunawan, Ni Made Yeni Suranti, F. (2020). Variations of Models and Learning Platforms for Prospective Teachers During the COVID-19 Pandemic Period. Indonesian Journal of Teacher Education, volume 1(2), 61-70.

Hisyam Zaini dkk. (2008). Strategi Pembelajaran Aktif. Yogyakarta: Insan Madani

Hamruni. (2011). Strategi Pembelajaran. Yogyakarta: Insan Madani

Ibrahim, D. S., \& Suardiman, S. P. (2014). Pengaruh Penggunaan E -Learning Terhadap Motivasi Dan Prestasi Belajar Matematika Siswa Sd Negeri Tahunan Yogyakarta. Jurnal Prima Edukasia, volume 2(1), 66. https://doi.org/10.21831/jpe.v2i1.2645.

Jamaluddin, Dindin. (2020). Pembelajaran Daring Masa Pandemi Covid-19 pada Calon Guru: Hambatan, Solusi, dan Proyeksi. Karya Tulis Ilmiah, Lembaga Penelitian dan Pengabdian Kepada Masyarakat UIN Sunan Gunung Djati Bandung, hal: 4 - 8.

Mulyasa. (2013). Pengembangan dan Implementasi Kurikulum 2013. Bandung: PT Remaja Rosdakarya

Nakayama M, Yamamoto H, \& S. R. (2007). The Impact of Learner Characterics on Learning Performance in Hybrid Courses among Japanese Students. Elektronic Journal ELearning, Volume 5(3).1.

Nur Laela Dewi, Ahmad Izza Muttaqin, A. M. (2019). Implementasi Strategi Information Searchdengan Memaksimalkan Penggunaan Smartphonedalam Pembelajaran Pai Kelas X MIPA 1 Di SMA Negeril Genteng Tahun Pelajaran 2018/2019. Tarbiyatuna: Kajian Pendidikan Islam, volume 3(2). https://doi.org/10.1017/CBO9781107415324.004

Pranoto. (2020). Pelatihan Digital Marketing Untuk Peningkatan Perekonomian Anggota Karang Taruna Al Barkah Di Kampung Cicayur-Tangerang. Jurnal Pengabdian Dharma Laksana, volume 1, hal: 260-258.

Purwanto, A., Pramono, R., Asbari, M., Budi Santoso, P., Mayesti Wijayanti, L., Chi Hyun, C., \& Setyowati Putri, R. (2020). Universitas Muhammadiyah Enrekang Studi Eksploratif Dampak Pandemi COVID-19 Terhadap Proses Pembelajaran Online di Sekolah Dasar. Edupsycouns Journal, volume 2, hal: 1-12.

Sapuadi dan Yana Sari. (2019). Upaya Meningkatkan Hasil Belajar Siswa Kelas VII-B MTs Darul Amin Palangka Raya pada Pembelajaran Sejarah Kebudayaan Islam Melalui Metode Information Search. Journal of Classroom Action Research, volume 1 (1), hal: 14-21.

Sodikin, M. A., Sumardi, K., \& Berman, E. T. (2018). Penerapan Metode Information Search Untuk Meningkatkan Kemampuan Literasi Informasi Peserta Didik Pada Mata Pelajaran Kontrol Refrigerasi Dan Tata Udara. Journal of Mechanical Engineering Education, volume 5(1), hal: 50-60. https://doi.org/10.17509/jmee.v5i1.12619. 